\title{
TELAAH SITOTOKSIK DARI EKSTRAK KARANG LUNAK Nephtea sp.
}

\author{
(Study cytotoxic from soft coral Nephtea sp.) \\ Antonius P. Rumengan ${ }^{1^{\star}}$, Remy E.P. Mangindaan ${ }^{1}$ \\ 1 Program Studi IImu Kelautan, Fakultas Perikanan dan IImu Kelautan, Universitas Sam \\ Ratulangi Manado. \\ *e-mail : antonius_rumengan@unsrat.ac.id
}

Cytotoxic bioassay is the early stage in encountering potential antitumor compounds. Soft coral is one of marine organisms which already been reported produces many bioactive substances. However, cytotoxic activity of Nephtea sp has not been reported yet. Therefore, it is require to conduct are search to find its cytotoxic activity. The purpose of the research was to know wheter the sample have the cytotoxic activity against the fertilized sea urchin eggs and the development of sea urchin embryos Tripneustes $\mathrm{sp}$. The sample was extracted with methanol to obtain methanolic extract. Methanolic extract was partitioned with ethyl acetate, hexane and chloroform to give three fractions. All fractions were tested against the development of sea urchin embryos. The result of the research revealed that methanolic extract inhibited the development of sea urchin embryos as well as prevented the cleavage of fertilization membrane. On the other hand, all three fractions demonstrated high cytotoxic activity by inhibiting both the development of Sea urchin embryos and preventing the cleavage of fertirtilization membrane. However it is necessary to purify each fraction to obtain pure compounds.

Keywords: cytotoxic, soft coral, Nepthea sp., Tripneustes sp, bioactive

Telaah aktivitas sitotoksik merupakan langkah awal dalam pencarian senyawa baru yang potensial sebagai antitumor, antara lain berasal dari bahan hayati laut. Karang lunak berpotensi dalam penyediaan substansi bioaktif yang memiliki aktivitas sitotoksik. Sampel karang lunak Nephtea sp diekstraksi dengan pelarut methanol, kemudian dipartisi dengan menggunakan pelarut etil asetat, heksan dan kloroform. Ekstrak dari hasil ekstraksi dan partisi diuji aktivitas sitotoksiknya pada sel telur bulu babi Tripneustes sp. Pengamatan untuk ekstrak metanolik menghambat perkembangan embrio pada perlakuan setelah fertilisasi hanya memperlambat perkembangan embrio bulu babi sedangkan untuk fraksi larut etil asetat, heksan dan kloroform dari kedua perlakuan memiliki aktivitas sitotoksik yang tinggi dengan menghambat perkembangan embrio bulu babi Tripneustes sp. Karang lunak Nephtea sp mengandung senyawa yang memiliki aktivitas sitotoksik yang tinggi. Untuk itu perlu dilakukan pemurnian senyawa lebih lanjut.

Kata kunci : sitotoksik, karang lunak, Nepthea sp., Tripneustes sp, bioaktifitas

\section{PENDAHULUAN}

Organisme hidup tidak terkecuali biota laut menghasilkan berbagai produk alami yang terdiri dari metabolit primer dan metabolit sekunder. Metabolit primer merupakan substansi yang dihasilkan dari proses metabolisme dasar untuk pertumbuhan dan perkembangan organisme yang bersangkutan dan tersebar luas secara alamiah pada setiap organisme. Sedangkan metabolit sekunder adalah substansi kimia yang dihasilkan sering digunakan untuk perlindungan diri terhadap predator-predator lingkungannya.

Karang lunak merupakan salah satu jenis biota laut yang menjanjikan nilai farmakologisnya yang berasal dari 
daerah terumbu karang (Honda dalam Sammarco dan Coll, 1988). Senyawa toksik oleh karang lunak digunakan untuk antipredasi dan kompetisi dalam memperoleh ruang. Coll dalam La Barre dkk, (1986) melaporkan karang lunak menjadi sumber protein, karbohidrat terutama lemak yang potensial dan beberapa di antaranya telah diteliti mengandung substansi yang bersifat toksik (Coll dkk, 1982 ; Scheuer, 1978). Dimpudus (1997) dan Kapojos (2002) melaporkan adanya aktivitas sitotoksik dari ekstrak karang lunak.

Telaah aktivitas sitotoksik merupakan langkah awal dalam pencarian senyawa baru yang potensial sebagai antitumor, antara lain berasal dari bahan hayati laut. Masih banyak spesies karang lunak yang belum diteliti aktivitas sitotoksiknya padahal kandungan senyawa terpen yang bersifat toksik dari tiap spesies karang lunak berbeda-beda. Untuk itulah penelitian ini dilakukan.

\section{METODE PENELITIAN}

\section{Pengambilan Sampel}

Sampel diambil dari perairan Teluk Manado dengan bantuan alat selam. Selanjutnya sampel dimasukkan ke dalam kotak plastik dan dibawa ke laboratorium untuk diteliti.

\section{Ekstraksi Karang Lunak}

Sampel sebanyak $1 \mathrm{~kg}$, dimaserasi dalam etanol selama 24 jam. Ekstrak difiltrasi sehingga didapatkan ekstrak etanolik. Ekstrak etanolik inilah yang akan diuji aktivitasnya dan selanjutnya ekstrak etanolik ini akan dipartisi.

\section{Partisi}

Ekstrak etanolik karang lunak Nepthea sp dipartisi berdasarkan polaritas. Ekstrak ini dilarutkan kedalam $\mathrm{MeOH}: \mathrm{H}_{2} \mathrm{O}$ (9:1) dan dimasukkan ke dalam labu pemisah (separatory funnel). Larutan heksan ditambahkan kedalam labu pemisah kemudian dikocok, lalu didiamkan kurang lebih 30 menit untuk mendapatkan dua lapisan yaitu lapisan heksan dan lapisan metanol-air. Masing-masing lapisan ditampung dalam wadah yang berbeda. Lapisan heksan diuapkan menggunakan rotari vakum evaporator pada suhu di bawah $40^{\circ} \mathrm{C}$ hingga kering untuk mendapatkan fraksi heksan, ditimbang.

Lapisan metanol-air dimasukkan lagi kedalam labu pemisah kemudian ditambahkan etil asetat dengan perbandingan 1:3. Labu pemisah dikocok dan didiamkan sehingga terdapat dua lapisan yaitu lapisan etil asetat dan lapisan air. Lapisan etil asetat diuapkan menggunakan rotari vakum evaporator pada suhu $40^{\circ} \mathrm{C}$ hingga kering lalu ditimbang sehingga diperoleh fraksi etil asetat.

Lapisan air dipilah lagi dengan cara dimasukkan kedalam corong pemisah, kemudian ditambahkan n-butanol. Corong pemisah dikocok sehingga lapisan air dan butanol tercampur rata. Masa jenis butanol lebih ringan dari masa jenis air sehingga diperoleh dua lapisan yaitu lapisan butanol pada bagian atas dan lapisan air pada bagian bawah. Lapisan butanol yang diperoleh diuapkan menggunakan rotari vakum evaporator pada suhu $40^{\circ} \mathrm{C}$. Selanjutnya ekstrak dimasukkan ke dalam desikator hingga kering kemudian ditimbang dan diperoleh fraksi butanol.

\section{Persiapan Hewan Uji}

Hewan uji yang digunakan dalam pengujian ini adalah bulu babi Tripneustes sp. Bulu babi yang diambil memiliki ciri-ciri permukaan tubuh berwarna hitam tembaga, duri berwarna merah, coklat, putih dan ungu. Fertilisasi buatan dilakukan dengan cara bagian gonad diteteskan larutan $0,54 \mathrm{M} \mathrm{KCl}$ sehingga sel telur atau sperma akan keluar dengan sendirinya melalui lubang pelepasan, 
seperti yang dilakukan oleh Ante (2002).

Fertilisasi buatan yang
dilakukan dalam
menelitian ini
menggunakan dua sistem, yang pertama dengan cara menggabungkan sel telur dengan sel sperma ke dalam gelas piala yang berisi air laut saring sebagai standar. Setelah 30 menit diinkubasi, sel telur yang sudah dibuahi dimasukkan ke dalam tiap petridish yang sudah berisi ekstrak dengan konsentrasi 20 ppm sebanyak tiga kali ulangan.

\section{Pengujian Ekstrak}

Ekstrak etanolik dan fraksi-fraksi yang diperoleh dilarutkan dalam air laut saring dengan bantuan etanol hingga konsentrasi akhir menjadi $20 \mathrm{ppm}$. Setiap larutan dibuat sebanyak $20 \mathrm{ml}$ dalam tiap cawan petri. Ke dalam cawan-cawan ini dimasukkan sel telur yang telah dibuahi. Pada tiap-tiap pengamatan diambil beberapa tetes dari pertidish kemudian dituangkan ke dalam tabung reaksi, setalah itu tambahkan formalin $1 \%$ untuk menghindari terjadinya perkembangan sel selama perhitungan.

\section{HASIL DAN PEMBAHASAN}

\section{Hasil ekstraksi karang lunak yang diperoleh dikeringkan menggunakan desikator. Berat ekstrak yang diperoleh yaitu 32 g. Ekstrak etanolik ini diuji aktivitas sitotoksik terhadap perkembangan zygot bulu babi dan antibakteri.}

\section{Pengujian aktivitas sitotoksik dari ekstrak etanolik karang lunak Nephtea sp.}

Dalam pendeteksian awal pada Gambar 1 dilihat perkembangan sel sampai jam ke 48. Hal ini dimaksudkan agar dapat diamati proses perkembangan sel. Pengamatan yang dilakukan pada jam ke 48, sel-sel perlakuan tidak mengalami perkembangan. Setelah dibandingkan dengan kontrol, hasil pengujian aktivitas sitotoksik dari ekstrak etanolik karang lunak Nephtea sp dengan konsentrasi ekstrak 10 dan 100 ppm yang diujikan pada perkembangan awal embrio bulu babi memperlihatkan adanya aktivitas positif. Kedua konsentrasi yang tergambar dalam Gambar 1 menunjukkan aktivitas sitotoksik lebih dari $95 \%$ sampai pada pengamatan 48 jam. Hal ini menunjukan perlu untuk melihat aktivitas sitotoksik setelah ekstrak di partisi.

\section{Partisi dan Pengujiannya}

Ekstrak etanolik dipartisi menggunakan tiga jenis pelarut berdasarkan perbedaan polaritas. Pelarut heksan yang bersifat non polar memperoleh $0,78 \mathrm{~g}$ ekstrak fraksi heksan. Pelarut etil asetat dan butanol diperoleh ekstrak dengan berat masingmasing 0,0156 gr fraksi etil asetat dan $1,2819 \mathrm{gr}$ fraksi butanol.

Pengujian bioaktif masingmasing fraksi dilakukan pada tahap perkembangan awal sel bulu babi. Gambar 2 memperlihatkan aktivitas masing-masing fraksi. Fraksi heksan pada konsentrasi 10 dan 50 ppm menunjukkan aktivitas sitotoksik terunggul terhadap sel bulu babi. Pengamatan A dilakukan pada saat sel kontrol sudah lebih dari $50 \%$ terjadi pembelahan 2 dan saat sel sudah mencapai lebih dari $50 \%$ mengalami pembelahan $8, \quad$ dilakukanlah pengamatan $\mathrm{B}$.

Karang lunak Nephthea $s p$ memiliki metabolit sekunder golongan sesquiterpenoid dan turunannya dengan struktur yang beranekaragam. Beberapa dari golongan sesquiterpenoid ini memang memiliki aktifitas biologis seperti sitotoksik, antiinflamasi dan antibakteri. Dalam penelitian ini, menarik dilakukan penelitian lanjutan untuk mengetahui senyawa murni yang berperan sebagai senyawa sitotoksik. Selain itu penting juga melakukan penelitian lanjutan untuk mengetahui cara kerja dan dampak senyawa sitotoksiknya. 

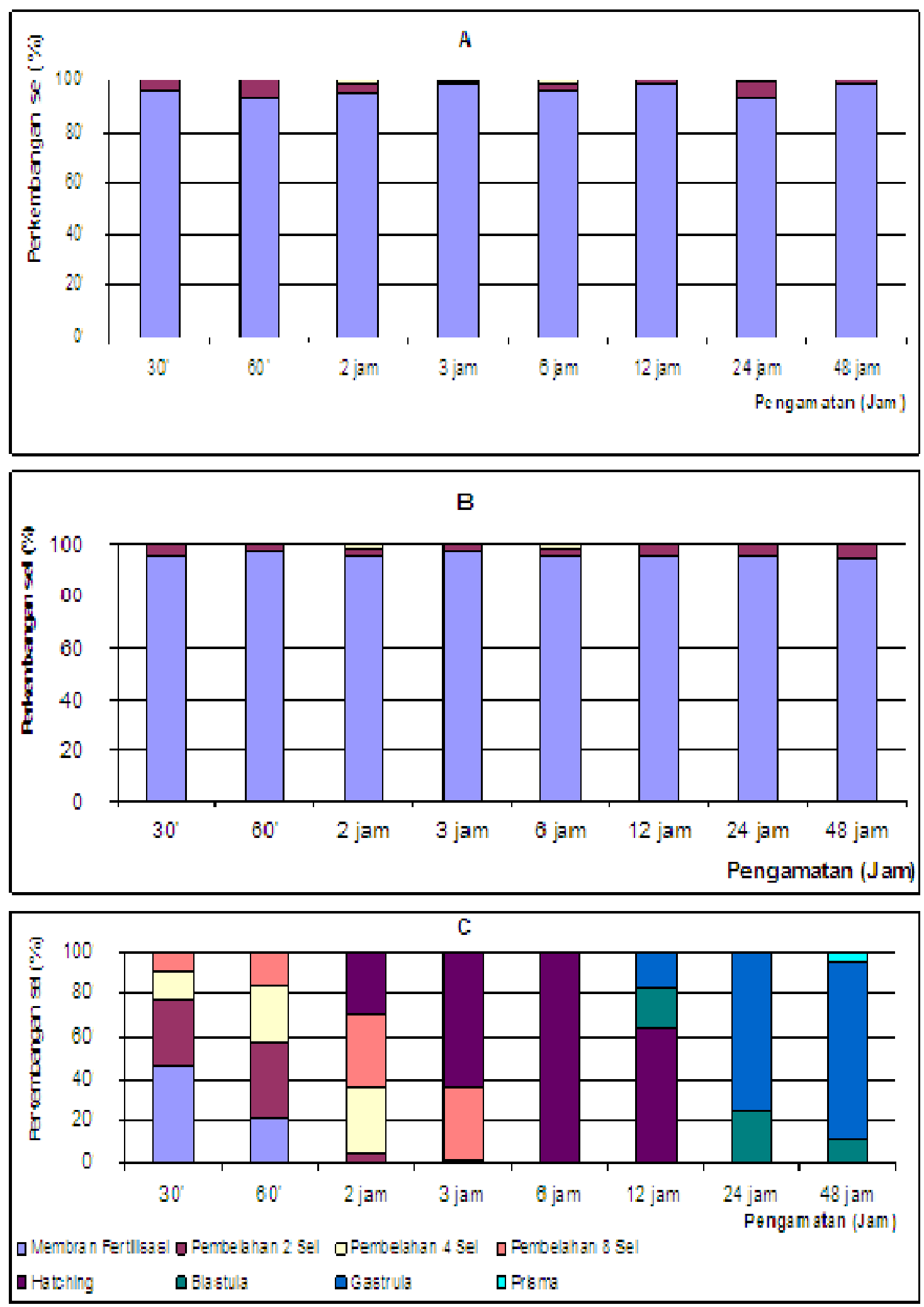

Ket : A. Grafik 10 ppm, B. Grafik 100 ppm, C. Grafik Kontrol

Gambar 1. Presentase perkembangan awal embrio bulu babi dengan perlakuan ekstrak etanolik karang lunak Nepthea sp 


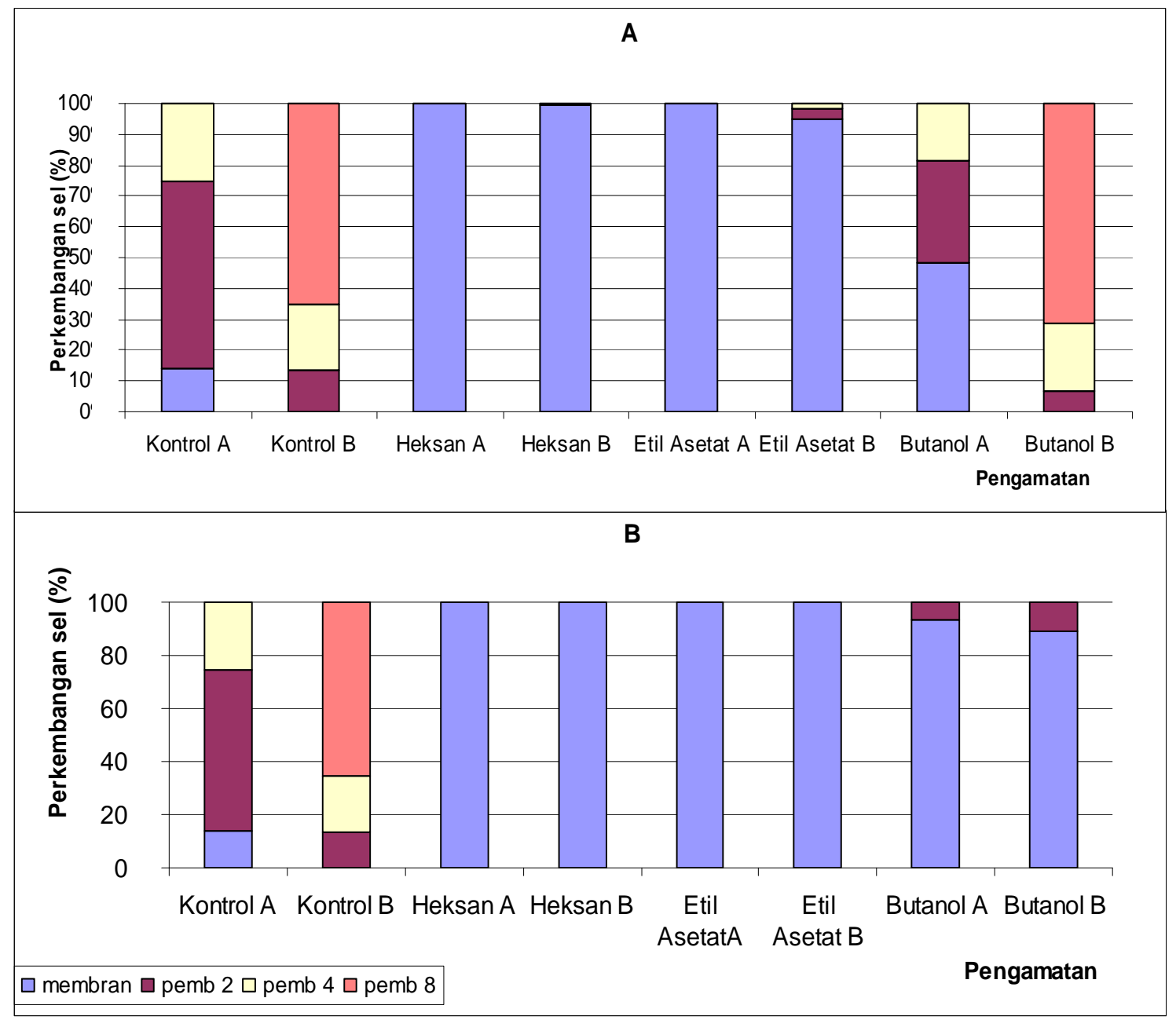

Ket : A. Grafik 10 ppm (pengamatan 2 sel), B. Grafik 50 ppm (pengamatan 8 sel).

Gambar 2. Presentase perkembangan awal embrio bulu babi dengan perlakuan ekstrak karang lunak Nepthea sp telah dipartisi

\section{KESIMPULAN DAN SARAN}

\section{Kesimpulan}

Berdasarkan hasil, maka dapat disimpulkan beberapa hal yaitu :

1. Karang lunak Nepthea $s p$ mengandung senyawa sitotoksik terhadap perkembangan awal embrio bulu babi Tripneustes sp.

2. Senyawa dengan aktivitas sitotoksik tertinggi terdapat dalam fraksi larut heksan

\section{Saran}

Untuk mendapatkan substansi sitotoksik yang dapat menghambat perkembangan sel sebaiknya dilakukan pemurnian terhadap fraksi larut heksan. Selain itu penting juga melakukan penelitian lanjutan untuk mengetahui cara kerja dan dampak senyawa sitotoksiknya bagi sel hidup.

\section{DAFTAR PUSTAKA}

Alex and Kyle. 1998. Sidwell Echinoderms

Educations.(http://sidwell.edu/us/sc ience /vlb/urchinlab.html). 8 mei 2008

Allen and Steene (2002). Marine Ecology Soft Coral. Academic 
Press; New York, San Francisco, London. 690 pp

Ante, Y. 2002. Aktivitas Penghambatan

Beberapa Ekstrak Sponge

Terhadap Perkembangan Awal

Embrio Bulu Babi Diadema

savignyi. Skripsi. Fakultas

Perikanan dan IImu Kelautan. UNSRAT. 45 hal.

Barnes, R.D. 1987. Invertebrate Zoology. W.B. Saunders Company, Philadelphia. London. 872 pp.

Bonang, G. dan W. S Koeswardono. 1982. Mikrobiologi Kedokteran Untuk Laboratorium Dan Klinik. Penerbit P.T Gramedia. Jakarta.

Campbell, Reece and Michel. 2000. Biologi. Penerbit Erlangga. Edisi Kelima - Jilid 2. Jakarta. 512 hal

Choi, Y. and F.J. Schmitz. 1997. Cytotoxic Sterol from the Soft Coral Nephthea erecta. J. Nat. Prod. 61 : p 1022-1024.

Coll, J.C., S. La Barre., P. W. Sammarco., W. T. Williams and G.J. Bakus. 1982. Chemical Defense in Soft Coral (Coelenterate : Octocorallia) of Great Barrier Reef 1 : A Study of Comparative Toxicities. Marine Ecology Progress Series Vol. 8: $p$ 271-278.

Dimpudus, M. T. 1997. Aktivitas Sitotoksik dari Beberapa Ekstrak Karang Lunak. Fakultas Perikanan dan IImu Kelautan. Skripsi Unsrat. Manado. $67 \mathrm{Hal}$.

Dube, H.C. 1978. Fungi Bacteria and Viruses. First Edition. Vikas Publisihing House. New Delhi Bombay. p 124-133.

Duh, C., S. Wang, M. Chu and J, Sheu. 1998. Cytotoxic Sterol from the Soft Coral Nephthea erecta. J. Nat Prod. 61 : p 1022-1024.

Faulkner, D.J. 1992. Jurnal. Marine Natural Product. Report vol 10. $\mathrm{p}$ 355-394.

Gan, S., Bambang S., Udin S., Arini S., dan Vincent. H. S. G. 1980. Farmakologi Dan Terapi. Edisi 2.
Fakultas Kedokteran Universitas Indonesia. Jakarta. 693 hal.

Gilbert, S. F. 1991. Development Biology. Sinaver Associates Inc. Sunderland Massacchusetts. p 57 117.

Iwamoto, C., T. Yamada, Y. Ito, K. Minoura and A. Numata. 2001. Cytotoxic Cytochalasans from a Penicillium Species Separated from a Marine Alga. Tetrahedron $57:$ p 2997-3004.

Jawetz, E., J. L. Melnick. dan E. A Adelberg. 1986. Mikrobiologi Untuk Profesi Kesehatan. Edisi 16. EGC. Penerbit Buku Kedokteran. $672 \mathrm{pp}$.

Kapojos, M.M, R.E.P. Mangindaan, Takahiro N, Taiko O,Kazuyo U, dan Michio N. 2008. Three New Nardosinane Type Sesquiterpenes form an Indonesian Soft Coral Nephthea sp. Chem. Pharm. Bull. Vol. 56, N0 3. p 332-334.

Katzung, B .G. 1986. Farmakologi Dasar Dan Klinik. Edisi Ketiga. Penerbit Buku Kedokteran. EGC. Hal 607-614.

Kobayashi, Namikosho, Yoshimoto dan Yokochi. 1996. A. Screening Method For Antimitotic and Antifungal substance Using Conidia of Pyricularia oryzae, Modification and Application to Tropical Marine Fungi. The Journal Of Antibiotics. Vol. 49 No 9. p 873879.

Kozloff, E.N.1990. Invertebrates. Sounders College Publishing. p 7491

La Barre, S., J.C. Coll and P.W. Sammarco, 1986. Defensive Strategis of Soft Coral (Coelenterate : Octocorallia) of Great Barrier Reef II : The Relationship Between Toxicity and Feeding Deterence. Biol. Bull. 171. p 565-576.

Lay, W. B. 1994. Analisis Mikroba Di laboratorium. PT RajaGrafindo persada. Jakarta. 168 hal.

Manuputty 2002. Aquacultural Production of Bryostatin 1 and 
Ecteinascidin 743. CalBioMarine Technologies Inc., Carlsbad, California, USA. Production Fusetani $\mathrm{N}(\mathrm{ed})$ :Drugs From the Sea. Basel, Switzerland. Karger. $p$ 120-133.

Mamuaya, C.E.Y. 2005. Uji Aktivitas sitotoksik Ekstrak Karang Lunak Sinularia sp terhadap perkembangan awal Embrio Bulu Babi T. gratila. Skripsi. Fakultas Perikanan dan IImu Kelautan, UNSRAT. Manado. 53 hal

Miftachul H dan Ika R 2008. Pemodelan Nonlinier Reaksi Difusi Pertumbuhan Kanker http://www.nano.lipi.go.id/utama.cgi ?artikel\& 1203647897.8 mei 2008

Sammarco dan Coll, 1988. Solution Structure of the Antitumor Candidate Trunkamide A by 2D NMR and Restrained Simulated Annealing Methods. Journal Organic Chemistry, Vol.68, No. 2. JOC Article, American Chemical Society. p 211-215.

Satari, R. 1998. Skreening Substansi Bioaktif dari Sponge sp. Asal Perairan Pulau Pari, Lombok Barat dan Spermonde dalam Produk Alami Laut Indonesia. Puslibang Oseanologi. LIPI. Jakarta. Hal 4356

Scheuer 1978.Cytotoxic Effect of Marine Toxins and Venoms. University of Minnesota. USA. 477 $\mathrm{pp}$

Setyabudi, R., H. U Sjamsudin. dan Z. E Bustami. 1982. Kombinasi Antimikroba. Penerbit Fakultas Kedokteran. Universitas Indonesia. Jakarta. 166 hal.

Shokita, S., Kakazu, A. Tamori dan Toma, 1991. Aquaculture in Tropical Areas. Published by Midori Shobo Co., Ltd. p 313-327.

Soeripto. 2002. Pendekatan Konsep Kesehatan Hewan Melalui Vaksinasi.

http://pustaka.bogor.net/publ/JP3/J P212-21.htm. 20 Juli 2008

Supardi, I dan Sukamto. 1990. Mikrobiologi Dalam Pengolahan
Dan Keamanan Pangan. Penerbit Alumni. Bandung. 290 hal.

Supriharyono. 2000. Pelestarian dan Pengelolaan Sumber Daya Alam di Wilayah Pesisir Tropis. Gamedia Pustaka Utama. Jakarta. Hal 1-11

Tursch, S., S. Matsunaga, N. Fusetani and A.Toh-e. 1978. Theopederins F-J : Five New Antifungal and Cytotoxic Metabolites from the Marine sponge, Theonella swinhoei.Tetrahedron 55: p1369713702. 